\title{
$\mathrm{Cr}_{2} \mathrm{O}_{3}-\mathrm{Cr}$ 成形体の炭素粉末中における焼結
}

\author{
山口明良 \\ (名古屋工業大学 無機材料工学科)
}

\begin{abstract}
$\mathrm{Cr}_{2} \mathrm{O}_{3}-\mathrm{Cr}$ 成形体の炭素粉末中における焼結, この焼結中に生成する $\mathrm{Cr}_{2}(\mathrm{C}, \mathrm{N})$, そして $\mathrm{Cr}$ と空 気他来する $\mathrm{N}_{2}$ 及び $\mathrm{CO}$ ガスとの反応について研究した。

$\mathrm{Cr}$ は約 $600^{\circ} \mathrm{C}$ 以上で $\mathrm{N}_{2}$ 及び $\mathrm{CO}$ ガスと反応した. そして $\mathrm{Cr}_{2}(\mathrm{C}, \mathrm{N})$ と少量の $\mathrm{Cr}_{2} \mathrm{O}_{3}$ が生成 し, $700^{\circ} \sim 1100^{\circ} \mathrm{C}$ ではその外に $\mathrm{CrN}$ が生成した。焼結中に生成した $\mathrm{Cr}_{2}(\mathrm{C}, \mathrm{N})$ 結晶中の $\mathrm{C}$ 含有 割合は， $1100^{\circ} \mathrm{C}$ 以下の焼成では 10 atom \% , その温度以上で直線的に減少し, $1500^{\circ} \mathrm{C}$ の焼成では 4 atom\% であった. $\mathrm{Cr}_{2} \mathrm{O}_{3}-\mathrm{Cr}$ 成形体は $1500^{\circ} \mathrm{C}$ の炭素粉末中での焼結で, $\mathrm{Cr}_{2}(\mathrm{C}, \mathrm{N})$ と $\mathrm{Cr}_{2} \mathrm{O}_{3}$ と からなる $95 \%$ 以上の相対密度のち密な焼結体となった. 特に, 約 $60 \% \mathrm{Cr}$ の成形体から得られた 焼結体の相対密度は $99 \%$ 以上であった。

(1979 年 12 月 18 日受付)
\end{abstract}

\section{Sintering of $\mathrm{Cr}_{2} \mathrm{O}_{3}-\mathrm{Cr}$ Compacts in Carbon Powder}

\author{
Akira YAMAGUCHI \\ (Department of Inorganic Materials, Nagoya Institute of Technology, Nagoya-shi 466)
}

\begin{abstract}
Sintering of $\mathrm{Cr}_{2} \mathrm{O}_{3}-\mathrm{Cr}$ compacts in carbon powder, $\mathrm{Cr}_{2}(\mathrm{C}, \mathrm{N})$ formation during the sintering, and reaction of $\mathrm{Cr}$ with gases $\left(\mathrm{N}_{2}\right.$ and $\left.\mathrm{CO}\right)$ originating from air were investigated.

$\mathrm{Cr}$ reacted with these gases to form $\mathrm{Cr}_{2}(\mathrm{C}, \mathrm{N})$ and a small amount of $\mathrm{Cr}_{2} \mathrm{O}_{3}$ at above $600^{\circ} \mathrm{C}$. In addition to these compounds ${ }^{\circ} \mathrm{CrN}$ was formed at $700^{\circ}$ to $1100^{\circ} \mathrm{C}$. The amount of $\mathrm{C}$ contained in $\mathrm{Cr}_{2}(\mathrm{G}, \mathrm{N})$ crystals formed during sintering was 10 atom $\%$ at below $1100^{\circ} \mathrm{C}$, and decreased linearly to 4 atom $\%$ at $1500^{\circ} \mathrm{C}$. $\mathrm{Cr}_{2} \mathrm{O}_{3}-\mathrm{Cr}$ compacts were sintered to high dense bodies composed of $\mathrm{Cr}_{2} \mathrm{O}_{3}$ and $\mathrm{Cr}_{2}(\mathrm{C}, \mathrm{N})$ at $1500^{\circ} \mathrm{C}$. The relative density of the bodies was above $95 \%$, and that of the body obtained from the compact of about $60 \% \mathrm{Cr}$ was above $99 \%$.

[Received December 18, 1979]
\end{abstract}

Key-words : $\mathrm{Cr}_{2} \mathrm{O}_{3}, \mathrm{Cr}_{2}(\mathrm{C}, \mathrm{N}), \mathrm{Cr}_{2} \mathrm{~N}$, Sintering in carbon powder

\section{1. 緒言}

著者は, 前報 ${ }^{1)} \mathrm{Cr}_{2} \mathrm{O}_{3}$ 単味の成形体の炭素粉末中で の焼結について 報告し，この焼結中に生成する $\mathrm{Cr}_{2}(\mathrm{C}$, N) が焼結に重要な役割をなすことを述べた。その後こ の $\mathrm{Cr}_{2}(\mathrm{C}, \mathrm{N})$ は， あらかじめ $\mathrm{Cr}$ 金属粉末を添加して おくことによって生成され， $\mathrm{Cr}_{2} \mathrm{O}_{3}$ をクラックも入らず 安定に焼結させるのに有効であることが分った．更に $\mathrm{Cr}$ 金属粉末混合量を増加させると, $\mathrm{Cr}_{2} \mathrm{O}_{3}$ と $\mathrm{Cr}_{2}(\mathrm{C}$, N) の任意の比率からなる極めてち密な複合焼結体が得 られることが分った。従来，この種の複合焼結体につい ての研究はなく, またいかなる特性があるかも不明であ り，今後明らかにしていくべき課題である．だが $\mathrm{Cr}_{2} \mathrm{O}_{3}$ がアルミナより融点が高く, 硬度も同じかそれ以上であ り，更に耐化学的侵食に優れるなどの特性があり，一方
$\mathrm{Cr}_{2}(\mathrm{C}, \mathrm{N})$ も比較的高融点であるとみられ, 電気伝導 性があるなどの特性があり，これらがち密に組み合わさ った焼結体は, 高温材料としてあるいは特殊磁器として 新しい用途が開発される可能性のある材料と考えられ た.

本研究は, 今後この焼結体の特性などを明らかにして いくのに先立ち, この焼結について, 及び Cr の炭素粉 末中での変化や生成物の $\mathrm{Cr}_{2}(\mathrm{C}, \mathrm{N})$ について明らかに したので報告する。

\section{2. 実験方法}

\section{1 試薬及び試料}

$\mathrm{Cr}_{2} \mathrm{O}_{3}$ 粉末 : $99.9 \% \mathrm{Cr}_{2} \mathrm{O}_{3}$ 特級試薬を使用した. 走査 型電子顕微鏡による 粒度測定では $0.2 \sim 1.0 \mu \mathrm{m}$ で平均 
$0.5 \mu \mathrm{m}$ であった.

$\mathrm{Cr}$ 金属粉末 : -200 メッシュの $99 \% \mathrm{Cr}$ 金属粉末試薬 を使用した。

炭素粉末 : 特級グラファイト試薬を使用した.

成形体試料: $\mathrm{Cr}_{2} \mathrm{O}_{3}$ 粉末と $\mathrm{Cr}$ 粉末とをアセトンを用 いて湿式混合し，この混合粉末を成形器に入れ， $1 \mathrm{t} / \mathrm{cm}^{2}$ の圧力で $20 \times 20 \times(10 \sim 15) \mathrm{mm}$ の正方板状に成形した ものを試料とした。

\section{2 焼成}

炭素粉末中及び窒素ガス中での焼成を次のように行っ た. 炭素粉末中の焼成は，2３個の成形体試料を約 30 ccのアルミナるつぼに入れ，この試料周囲に炭素粉末を 十分に充てんしてふたをし，このるつぼを所定温度にな った炉中に入れ所定時閒保持することによって行った。 その後るつぼを炬外に取り出し急冷した。焼成後も試料 は十分に炭素粉末によっておおわれていた，窒素ガス中 での焼成は，垂直にアルミナ炉心管のある炉中に試料を 白金線でつるし，その中に $\mathrm{N}_{2}$ ガスを $21 / \mathrm{min}$ で流すこ とによって行った.

\section{3 測定及び顕微鏡観察}

$1300^{\circ} \mathrm{C}$ 以上で焼成した試料の表面には, $\mathrm{Cr}_{2}(\mathrm{C}, \mathrm{N})$ と $\mathrm{Cr}_{7} \mathrm{C}_{3}$ より成る，はく離しやすい $0.1 \sim 0.5 \mathrm{~mm}$ の反応 層が生成していた。この層を除去した後にかさ密度を測 定し, 更に粉砕してピクノメーターによって真密度を求 めた. また粉砕物に内部標準として Si 粉末を混合して $\mathrm{X}$ 線分析を行い, 回折角を測定し, それより生成した $\mathrm{Cr}_{2}$ $(\mathrm{C}, \mathrm{N})$ の格子定数を算出した. 他の一つの試料におい ては, 中央部を切断し, ポリエステル樹脂に埋め込み, それを研磨し，1 $\mathrm{m}$ ダイヤモンドペーストで研磨仕上 げを行った.この研磨面について， EPMA によって $\mathrm{Cr}, \mathrm{O}, \mathrm{N}$ 及び C の分布状態を分析し, 反射顕微鏡によ って $\mathrm{Cr}_{2} \mathrm{O}_{3}$ と $\mathrm{Cr}_{2}(\mathrm{C}, \mathrm{N})$ の分布状態を観察した。 また 破断面の微構造を走查型電子顕微鏡によって観察した.

\section{3. $\mathbf{C r}-\mathbf{C}-\mathbf{N}$ 系化合物に関する従来の研究}

炭素粉末中に埋め込まれた試料内部及び炭素粉末中に 存在した空気中の酸素は, 炭素との反応によって $\mathrm{CO}$ ガ スとなり，試料の内部や周囲にはこの $\mathrm{CO}$ ガスと空気に 由来する $\mathrm{N}_{2}$ ガスとが共存すると考えてよい，そして $\mathrm{Cr}$ や $\mathrm{Cr}_{2} \mathrm{O}_{3}$ とこれらガスとの反応によって生成する化 合物は, $\mathrm{Cr}-\mathrm{C}-\mathrm{N}$ 系化合物であるので，まず $\mathrm{Cr}-\mathrm{C}-\mathrm{N}$ 系 化合物についての従来の研究を概観しておく.

$\mathrm{Cr}-\mathrm{N} 2$ 成分系には $\mathrm{CrN}$ 及び $\mathrm{Cr}_{2} \mathrm{~N}$ の 2 種類の化合物 が存在する. $\mathrm{Cr}_{2} \mathrm{~N}$ は不定比化合物で, $\mathrm{N}$ の割合が $\mathrm{Cr}_{2} \mathrm{~N}$ の化学式に相当するよりも常に少なく, $N_{\mathrm{N}} / N_{\mathrm{Cr}}$ が 0.376 にまでも小さくなることが，そして六方晶系に属し通常 の hcp 格子とみなし $N_{\mathrm{N}} / N_{\mathrm{Cr}}$ に対する $a_{0}{ }^{\prime}(2.7427 \sim$ $2.7756 \AA$ 兄 と $c_{0}(4.4296 \sim 4.4809 \AA)$ とが, Schwerdt. feger ${ }^{2)}$ によって報告されている。他方, $\mathrm{Cr}_{2} \mathrm{~N}$ の結晶構 造は超格子構造であるとして， $a_{0}=4.805, c_{0}=4.479 \AA$ の報告 ${ }^{3)}$ もるる。 また Ettmayer ${ }^{4)}$ は, $\mathrm{Cr}_{2}(\mathrm{C}, \mathrm{N})$ に関 する研究の中で $N_{\mathrm{C}} / N_{\mathrm{N}}$ の変化に対する格子定数変化に ついて述べ, $N_{\mathrm{C}} / N_{\mathrm{N}}$ の増大に伴って幾つかの回折線が 分裂することから斜方晶系に属するとした．しかしCが 10 atom $\%$ 以下では回折線は分裂せず，六方晶系として の指数づけも可能である. 六方晶系とした場合には $b_{0}=$ $(2 / \sqrt{3}) a_{0}$ の関係にあり, $\mathrm{Cr}_{2} \mathrm{~N}$ については, $a_{0}=4.821$, $c_{0}=4.491 \AA$ ，の值となる. 上述の通常の hep 格子とみ なした場合の $a_{0}{ }^{\prime}$ と, 超格子構造をとる場合の $a_{0}$ とは, $a_{0}=a_{0}{ }^{\prime} \sqrt{3}$ の関係にある. どちらの構造であるか定か でなく更に明らかにされるべきであるが，ここでは一応 上述の $a_{0}$ の格子定数に基づいて考える. $\mathrm{Cr}_{2} \mathrm{~N}$ につい て特徵的なことは，不定比化合物であり， $N_{\mathrm{N}} / N_{\mathrm{Cr}}$ が変 化し，それとともに $a_{0}$ と $c_{0}$ が変化するにもかかわら ず， $c_{0} / a_{0}$ の值が常に一定であること常である.

$\mathrm{Cr}-\mathrm{C}$ 系には $\mathrm{Cr}_{23} \mathrm{C}_{6}, \mathrm{Cr}_{7} \mathrm{C}_{3}$ 及び $\mathrm{Cr}_{3} \mathrm{C}_{2}$ の 3 種類の化 合物が報告 ${ }^{5}$ されている。その外に $\mathrm{Cr}_{2} \mathrm{C}$ があり，それ は高温で安定に存在しないとの報告 ${ }^{6}$ がある. 更に $\mathrm{CrC}$ があり，非常に高温でのみ安定に存在するとみられてい る $^{4)}$.

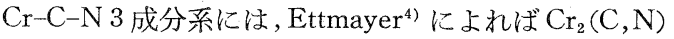
組成の化合物がある.そしてこれは，図１に示されるよ

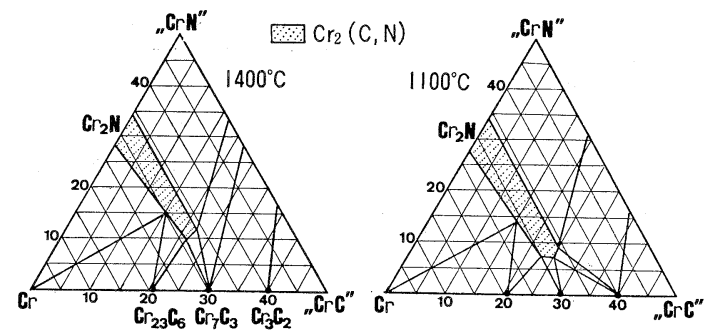

Fig. 1. Isothermal section of $\mathrm{Cr}-\mathrm{C}-\mathrm{N}$ system at $1400^{\circ}$ and $1100^{\circ} \mathrm{C}$. Nitrogen pressure $\leqq 1$ atm (after Ettmayer $\left.{ }^{4}\right)$.

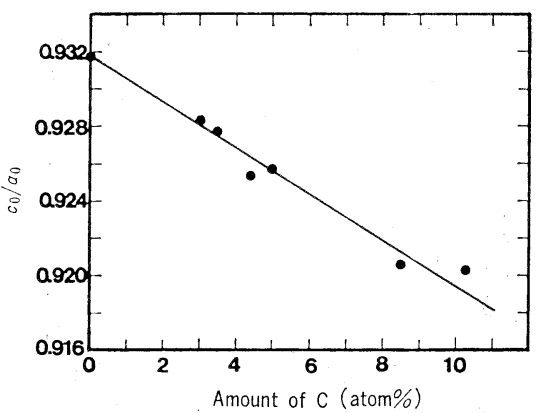

Fig. 2. Relation between $c_{0} / a_{0}$ and the amount of $\mathrm{C}$ in $\mathrm{Cr}_{2}(\mathrm{C}, \mathrm{N})$ crystal (based on the data of Ettmayer $\left.{ }^{4}\right)$. 
5に，ある範囲内で 組成が変動する 不定比化合物 であ る.この化合物の $N_{\mathrm{C}} / N_{\mathrm{N}}$ 比の小さい場合には，上述し たように，六方晶系の格子パラメーターに当てはまる。 しかし Cが 15 atom\% 以上になると，X 線回折線の幾 つかが分裂するようになることから斜方晶系として指数 ら゙けされいる。彼のデー夕に基づいて，六方晶系とみ なしてもよい 10 atom\% 以下の C を含有する組成のも のについて, C含有量と $c_{0} / a_{0}$ との関係を図示すると, 図 2 のよう直線関係が得られる。

\section{4. 実験 結果}

\section{$4.1 \mathrm{Cr}$ 金属粉末成形体の炭素粉末中及び 窒素ガス} 中での焼成における変化

炭素粉末中で $\mathrm{Cr}$ 金属粉末成形体を $500^{\circ} \sim 1000^{\circ} \mathrm{C}$ で 2 時間焼成したものを微粉砕して，すべて同一条件でX 線分析を行った．検出された物質の代表的な回折線の一 つを選んで, 焼成温度に対してその強度変化を図 3 に示 した. $500^{\circ} \mathrm{C}$ では $\mathrm{Cr}$ のみで変化がなく, $600^{\circ} \mathrm{C}$ では $\mathrm{Cr}_{2} \mathrm{O}_{3}$ と $\mathrm{Cr}_{2}(\mathrm{C}, \mathrm{N})$ の生成が認められ, $500^{\circ} \sim 600^{\circ} \mathrm{C}$ で 反応が始まることを示していた。 $\mathrm{CrN}$ は $700^{\circ} \sim 1100^{\circ} \mathrm{C}$ で生成し, $900^{\circ} \mathrm{C}$ で最大であった. $1300^{\circ} \mathrm{C}$ 以上では $\mathrm{CrN}$ はなく, $\mathrm{Cr}_{2}(\mathrm{C}, \mathrm{N})$ と少量の $\mathrm{Cr}_{2} \mathrm{O}_{3}$ が生成した.この $\mathrm{Cr}_{2}(\mathrm{C}, \mathrm{N})$ の格子定数は, 焼成温度に対して図 5 のよう に変化した。 $a_{0}$ と $c_{0}$ のいずれもが $1200^{\circ} \mathrm{C}$ 前後から温 度の上昇とともに減少し, 一方 $c_{0} / a_{0}$ 比は約 $1100^{\circ} \mathrm{C}$ 以

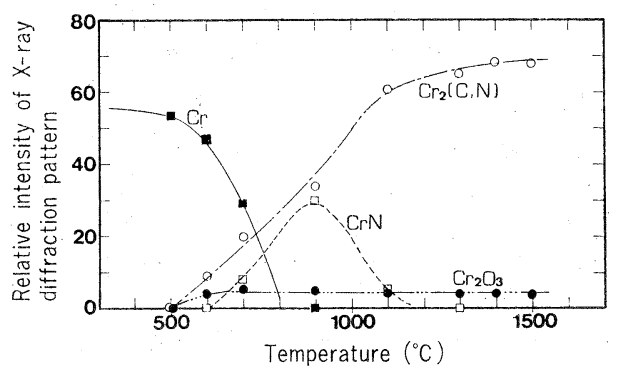

Fig. 3. Reaction products in $\mathrm{Cr}$-compact sintered in carbon powder at various temperatures for $2 \mathrm{~h}$.

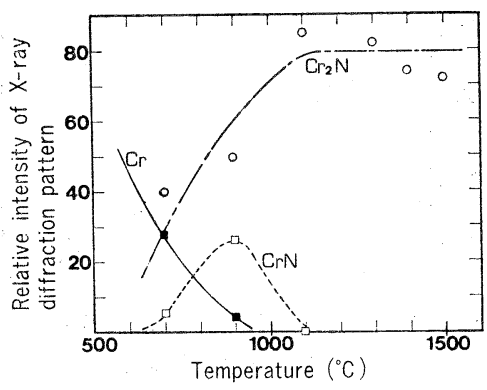

Fig. 4. Reaction products in Cr-compact sintered in $\mathrm{N}_{2}$ atmosphere at various temperatures for $30 \mathrm{~min}$.

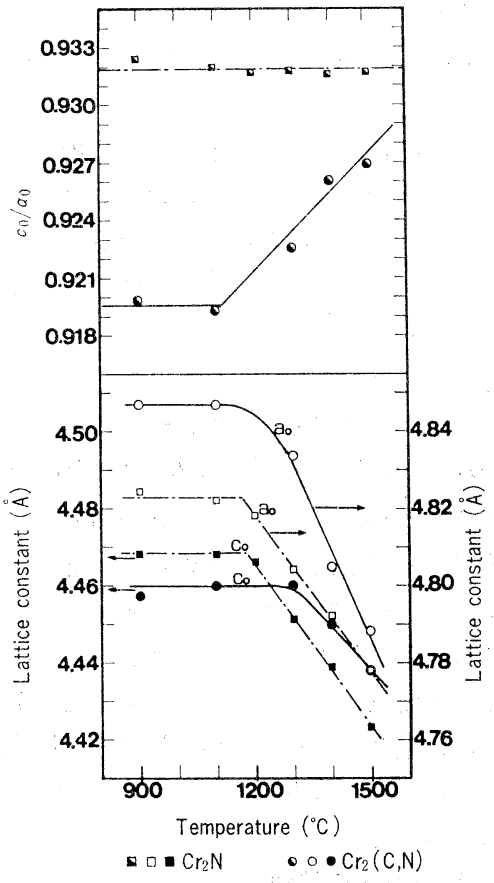

Fig. 5. Lattice constants of $\mathrm{Cr}_{2}(\mathrm{C}, \mathrm{N})$ and $\mathrm{Cr}_{2} \mathrm{~N}$ formed in the $\mathrm{Cr}$-compacts sintered in carbon powder for $2 \mathrm{~h}$ and in $\mathrm{N}_{2}$ gas for $30 \mathrm{~min}$, respectively.

上で直線的に増大した。

窒素ガス中で各温度で 30 分間焼成した場合には, 図 4 に示されるように, 上述の炭素粉末中での焼成におけ る生成物変化と比較して, $\mathrm{CrN}$ の生成傾向はほぼ同じ で, $\mathrm{Cr}_{2} \mathrm{~N}$ のそれは $\mathrm{Cr}_{2}(\mathrm{C}, \mathrm{N})$ にほぼ対応していた。 $\mathrm{Cr}_{2} \mathrm{~N}$ の格子定数の $a_{0}$ と $c_{0}$ のそれぞれは, 図 5 のよ 5 亿約 $1200^{\circ} \mathrm{C}$ 以上で減少したが，しかし $c_{0} / a_{0}$ 比は一 定值 (0.932) を示した.

\section{$4.2 \mathrm{Cr}_{2} \mathrm{O}_{3}-\mathrm{Cr}$ 混合粉末成形体の 炭素粉末中での焼} 結

図 6 は, $\mathrm{Cr}_{2} \mathrm{O}_{3}$ と $\mathrm{Cr}$ との混合粉末成形体を $1500^{\circ} \mathrm{C}$ で 2 時間炭素粉末中で焼成したものについて,かさ密度,真 密度, 相対密度 (かさ密度の真密度に対する割合)を,及び 燒結物の粉末 $\mathrm{X}$ 線回折で検出された $\mathrm{Cr}_{2} \mathrm{O}_{3}$ と $\mathrm{Cr}_{2}(\mathrm{C}, \mathrm{N})$ について代表的な回折線の強度を, 出発原料組成に対し て図示したものである:この時生成する $\mathrm{Cr}_{2}(\mathrm{C}, \mathrm{N})$ の $a_{0}$ と $c_{0}$ とは, 前述の $\mathrm{Cr}$ 粉末のみからなる成形体を $1500^{\circ} \mathrm{C}$ で炭素粉末中で焼成した場合とほぼ同じであっ た. Cr 単味の場合を除いて，いずれも $95 \%$ 以上の相対 密度にち密に焼結されており， $62 \% \mathrm{Cr}$ からの試料では 99\%を越えていた。図 7 は焼結体の破断面の走查型電 子顕微鏡写真である.いずれも表面付近と内部とでは， 微構造にほとんど差異は認められなかった. $\mathrm{Cr}$ 量の少 ない試料（図 $7 \mathrm{~A}, \mathrm{~B} ， \mathrm{C}$ ) 加の焼結体において，粒内 
や粒界に球状の気孔がかなり認められた．Cr 量が多く なるにしたがって（D，E）粒内の球状の気孔は少なく なり, 粒界のところどころに比較的大きな気孔が諗めら れた.しかし $62 \% \mathrm{Cr}$ の試料（F) ではほとんど気孔は

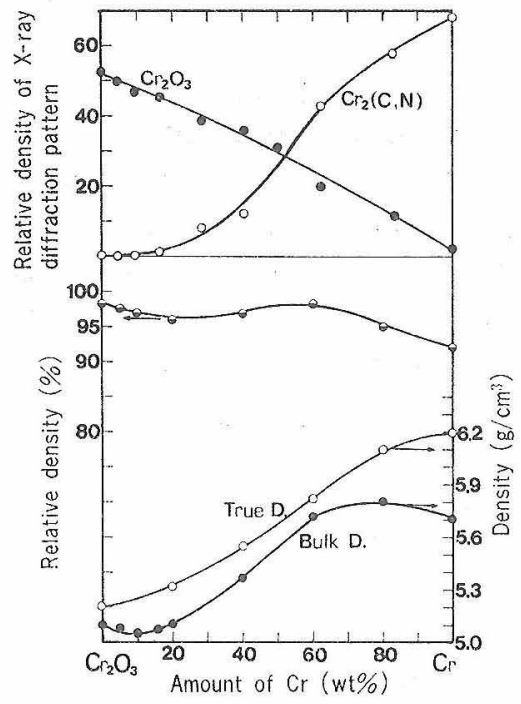

Tig. 6. Reaction products and densities or $\mathrm{Cr}_{2} \mathrm{O}_{3}$ - $\mathrm{Cr}$ compacts sintered in carbon powder at $1500^{\circ} \mathrm{C}$ for $2 \mathrm{~h}$.
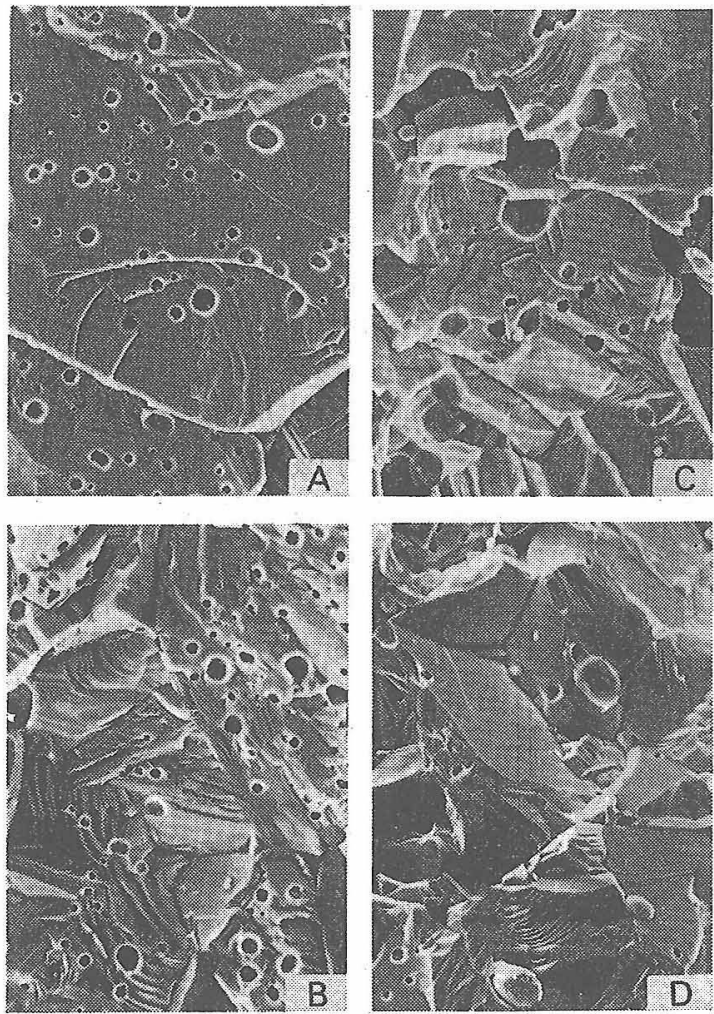
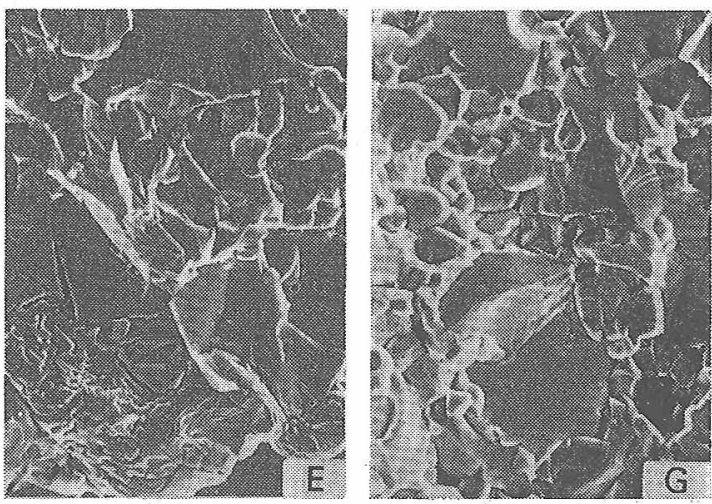

認められず最もら密に焼結されていた。 また $\mathrm{Cr}_{2} \mathrm{O}_{3}$ 粒 と $\mathrm{Cr}_{2}(\mathrm{C}, \mathrm{N})$ 粒との区別は明りょうでないが，粒径は Cr が多くなるにしたがって小さくなって括り， $62 \% \mathrm{Cr}$ 試料の焼結体では小さな比較的均一な粒の集合体となっ ていた。しかし更に Cr の割合の多い試料 $(\mathrm{G}, \mathrm{H})$ から は大きく成長した粒も現れ，また粒界に比較的大きな気 孔が生じていた。

次に，これら焼結体の研磨面を反射顕微鏡で観繁する と, $\mathrm{Cr}_{2}(\mathrm{C}, \mathrm{N})$ と $\mathrm{Cr}_{2} \mathrm{O}_{3}$ とは, 図 8,9 と示されるよう に，白い部分と灰色部分とに観察され明りょうに識別で きた. 図 8 はこの一例として, $10 \mathrm{Cr}_{2} \mathrm{O}_{3}-90 \mathrm{wt} \% \mathrm{Cr}$ 混合 試料からの燒結体について反射顕微鏡と EPMA での観 察とを対応させたものである. 更に上述の粉末 $\mathrm{X}$ 線回折 の結果で, $\mathrm{Cr}_{2} \mathrm{O}_{3}-\mathrm{Cr}$ 混合試料加らの焼結体には $\mathrm{Cr}_{2} \mathrm{O}_{3}$ と $\mathrm{Cr}_{2}(\mathrm{C}, \mathrm{N})$ の 2 種類の結晶からのみ構成されている ことを対応させると，白い部分には $\mathrm{C}$ と $\mathrm{N}$ が含まれ $\mathrm{Cr}_{2}(\mathrm{C}, \mathrm{N})$ であることが，灰色の部分は $\mathrm{O}$ が含まれ $\mathrm{Cr}_{2} \mathrm{O}_{3}$ であることが分る。また 10\% 以下の Cr 添加や無添加 試料では，X線回折において $\mathrm{Cr}_{2}(\mathrm{C}, \mathrm{N})$ は検出されな いものの，図 $9 \mathrm{~A}$ に一例が 示されるように，白い部分 がところどころ観察され，上記の結果からみて，これは $\mathrm{Cr}_{2}(\mathrm{C}, \mathrm{N})$ であることが推定できる.
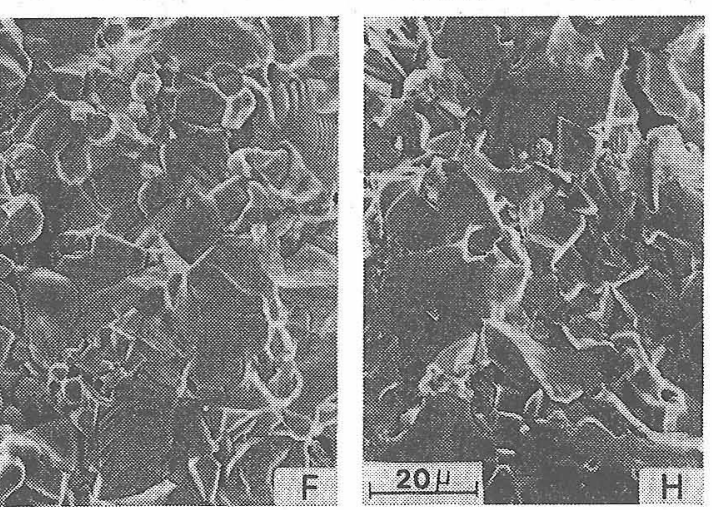

Fig. 7. SEM of $\mathrm{Cr}_{2} \mathrm{O}_{3}-\mathrm{Cr}$ compacts sintered in carbon powder at $1500^{\circ} \mathrm{C}$ for $2 \mathrm{~h}$. $\mathrm{A}: 0.5, \mathrm{~B}: 5, \mathrm{C}: 9, \mathrm{D}: 17, \mathrm{E}: 34, \mathrm{~F}: 62, \mathrm{G}: 83, \mathrm{H}: 100 \%$ (Cr wt $\%$ in compact.) 


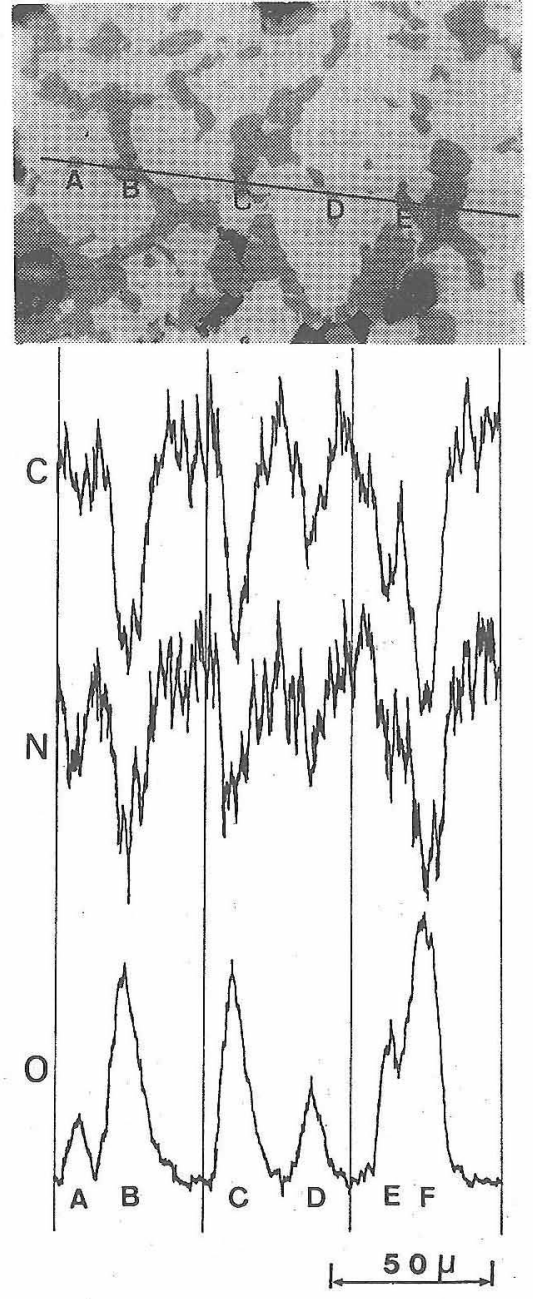

Fig. 8. EPMA of $\mathrm{Cr}_{2} \mathrm{O}_{3}-\mathrm{Cr}$ compact (Cr : 90 wt $\%$ ) sintered in carbon powder at $1500^{\circ} \mathrm{C}$ for $2 \mathrm{~h}$.

\section{5. 考察}

以上の結果加ら分るように, $\mathrm{Cr}_{2} \mathrm{O}_{3}$ と $\mathrm{Cr}$ との混合成 形体の炭素粉末中における焼成過程では，Cr が $\mathrm{CO}$ や $\mathrm{N}_{2}$ ガスと反応すること，及びち密化焼結することが起 こる。したがって，以下に $\mathrm{Cr}$ と $\mathrm{CO}$ 及び $\mathrm{N}_{2}$ ガスとの 反応生成物などについて考察し，次に $1500^{\circ} \mathrm{C}$ に扔ける ち密化焼結について考察する。

\section{1 焼結体中の反応生成物について}

図 3 と図 6 とから明らかなように， $1100^{\circ} \mathrm{C}$ 以上では $\mathrm{Cr}$ のほとんどが $\mathrm{Cr}_{2}(\mathrm{C}, \mathrm{N})$ となる。しかしこの場合， 図1で示されるように, $\mathrm{Cr}_{2}(\mathrm{C}, \mathrm{N})$ 結晶の組成において $N_{(\mathrm{N}+\mathrm{C})} / N_{\mathrm{Cr}}$ 及び $N_{\mathrm{N}} / N_{\mathrm{C}}$ が変化するので，炭素粉末中 で焼成された場合の生成物の組成について考えてみる.

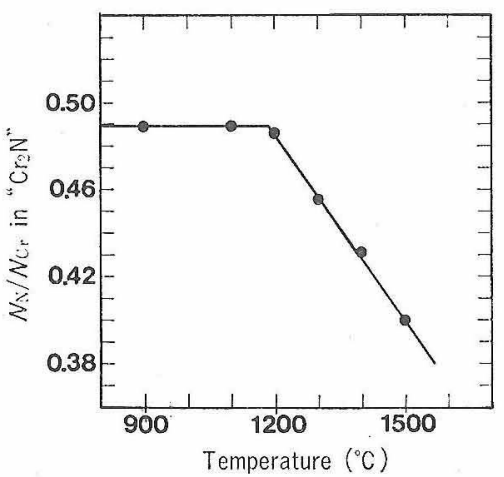

Fig. 10. $N_{\mathrm{N}} / N_{\mathrm{Cr}}$ in " $\mathrm{Cr}_{2} \mathrm{~N}$ " formed in $\mathrm{Cr}$ compact sintered in $\mathrm{N}_{2}$ atmosphere at various temperature for $30 \mathrm{~min}$.

Schwerdfeger ${ }^{2)}$ が報告するように，“ $\mathrm{Cr}_{2} \mathrm{~N}$ ” は不定比 化合物であり， $N_{\mathrm{N}} / N_{\mathrm{Cr}}$ が変化し， $a_{0}$ と $c_{0}$ もそれに応 ビて変化する. 図 10 は， $\mathrm{N}_{2}$ ガス中で焼成された $\mathrm{Cr}$ 成 形体に生成した “ $\mathrm{Cr}_{2} \mathrm{~N}$ ” の格子定数为ら, Schwerdfeger の求めた格子定数と $N_{\mathrm{N}} / N_{\mathrm{Cr}}$ との関係を刘応させて, 焼 成温度に対する $N_{\mathrm{N}} / N_{\mathrm{Cr}}$ の変化を求めた
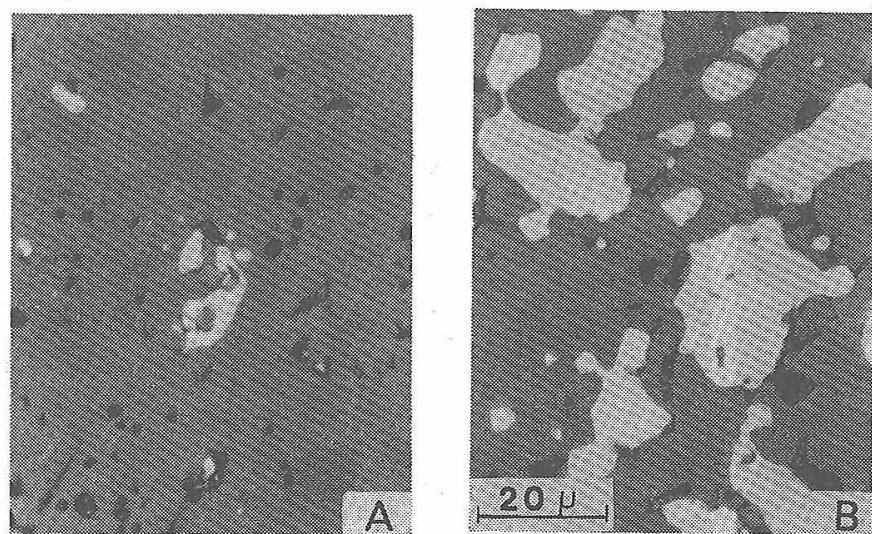

Fig. 9. Polished section of $\mathrm{Cr}_{2} \mathrm{O}_{3}-\mathrm{Cr}$ compact sintered in carbon powder at $1500^{\circ} \mathrm{C}$ for $2 \mathrm{~h}$. A : 0.5, B: $50 \%(\mathrm{Cr}$ wt\% in compact) White: $\mathrm{Cr}_{2}(\mathrm{C}, \mathrm{N})$, Gray : $\mathrm{Cr}_{2} \mathrm{O}_{3}$. ものである。約 $1200^{\circ} \mathrm{C}$ 以上から $\mathrm{N}$ の割合 は温度とともに直線的に小さくなってい る.しかしながら図 5 に示されるように， $c_{0} / a_{0}$ 比は常に一定であり，N の含有割合 に無関係であるといら特徽的な現象を示 す。したがって，図5で示される炭素粉末 中で生成する $\mathrm{Cr}_{2}(\mathrm{C}, \mathrm{N})$ 結晶の $c_{0} / a_{0}$ 比が 変化することは，Cの含有量の変動によっ てもたらされると推定できる，それ柿えに 図 2 の $\mathrm{Cr}_{2}(\mathrm{C}, \mathrm{N})$ 結晶の $c_{0} / a_{0}$ 比々含有 C量との関係に基ついて, 図 5 の $c_{0} j a_{0}$ 比 に対応寸る $\mathrm{Cr}_{2}(\mathrm{C}, \mathrm{N})$ 中の $\mathrm{C}$ 量を求为, 焼成温度に対してプロットすると，図 11 のようになる.これによって，本実験条件 のように，焼成前にあらかじめ空気が成形 


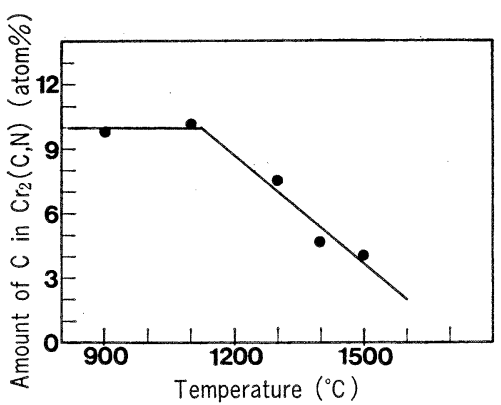

Fig. 11. The amount of $\mathrm{C}$ in $\mathrm{Cr}_{2}(\mathrm{C}, \mathrm{N})$ formed in $\mathrm{Cr}$-compact sintered in carbon powder at various temperatures for $2 \mathrm{~h}$.

体試料中や炭素粉末中に含まれることから由来する $\mathrm{N}_{2}$ ガスが共存する場合, $\mathrm{Cr}$ との反応によって生成する $\mathrm{Cr}_{2}$ (C, N) は, $1100^{\circ} \mathrm{C}$ 以下では C を約 10 atom\% 含むも のであり，焼成温度の上昇とともに C の少ないものと なり， $1500^{\circ} \mathrm{C}$ では約 4 atom\% の C を含むものになる ことが分る.

そして $\mathrm{Cr}_{2} \mathrm{O}_{3}$ を含む $\mathrm{Cr}_{2} \mathrm{O}_{3}-\mathrm{Cr}$ 混合成形体試料を $1500^{\circ} \mathrm{C}$ で焼成した場合も, Cr 単味の場合とほぼ同じ格 子定数の $\mathrm{Cr}_{2}(\mathrm{C}, \mathrm{N})$ が得られることから，約 4 atom\% のCを含んだ $\mathrm{Cr}_{2}(\mathrm{C}, \mathrm{N})$ が生成するものと考えられる.

$5.2 \mathrm{Cr}_{2} \mathrm{O}_{3}-\mathrm{Cr}$ 混合粉末成形体の炭素粉末中におけ るち密化焼結について

$\mathrm{Cr}_{2} \mathrm{O}_{3}$ 単味の粉末成形体の炭素粉末中での焼成におい ては，前報 ${ }^{1)}$ で報告したように, $1000^{\circ} \mathrm{C}$ 以下の温度では なんら変化を生じない，しかしながら，Cr も C も空気 中で加熱された場合に, 約 $600^{\circ} \mathrm{C}$ から酸化が始まること からみて, 本実験の $\mathrm{Cr}_{2} \mathrm{O}_{3}$ と $\mathrm{Cr}$ との混合粉末成形体の 炭素粉末中での焼成の場合に，燒成に際しての温度の上 昇時の約 $600^{\circ} \mathrm{C}$ から, 成形体中に内蔵されている空気中 の酸素の一部は $\mathrm{Cr}$ と反応して $\mathrm{Cr}_{2} \mathrm{O}_{3}$ となり, 他は $\mathrm{C}$ と反応して $\mathrm{CO}$ ガスとなると考えてよい. その結果，ち 密化の始まる $1000^{\circ} \mathrm{C}$ 以上では, 試料内部及び試料周囲 の炭素粉末中に存在するガスは，CO ガスと空気に由来 する $\mathrm{N}_{2}$ ガスとからなると考えられる.

そして, 図 3 で示されるように, $\mathrm{Cr}$ 粉末のみの成形 体が $1100^{\circ} \mathrm{C}$ 以上で $\mathrm{Cr}_{2}(\mathrm{C}, \mathrm{N})$ と少量の $\mathrm{Cr}_{2} \mathrm{O}_{3}$ とになる ことからみて, $\mathrm{Cr}_{2} \mathrm{O}_{3}$ と $\mathrm{Cr}$ との混合粉末成形体は, ち 密化の始まる以前に既に $\mathrm{Cr}_{2} \mathrm{O}_{3}$ と $\mathrm{Cr}_{2}(\mathrm{C}, \mathrm{N})$ との混合 体になっているとみてよい，そしてこの混合体の $1400^{\circ}$ $\sim 1500^{\circ} \mathrm{C}$ に扔けるち密化焼結は, 次の理由により $\mathrm{Cr}_{2} \mathrm{O}_{3}$ 単味の焼結機構とほぼ同じ機構で進むものと推察され る.すなわち，前報1で記述したように，本実験のよう に過㮃の炭素があり，ふたをされた容器中での酸素分圧 は, ほぼ $2 \mathrm{C}+\mathrm{O}_{2}=2 \mathrm{CO}$ の反応の平衡素分圧に近いと みられる. そしてその酸素分圧は， $1400^{\circ} \sim 1500^{\circ} \mathrm{C}$ にお いて $4 / 3 \mathrm{Cr}+\mathrm{O}_{2}=2 / 3 \mathrm{Cr}_{2} \mathrm{O}_{3}$ の反応の平衡酸素分圧より
2〜3 けた低い。そのため $\mathrm{Cr}_{2} \mathrm{O}_{3}$ の焼結の場合に，各 $\mathrm{Cr}_{2} \mathrm{O}_{3}$ 粒子の表面付近では酸素が失われやすくなり, 酸 素格子点で空孔の生じた $\mathrm{Cr}_{3} \mathrm{O}_{4}$ に, 又は更に酸素比の少 ない無秩序に近い状態になることが考えられる（これに 関し, Stone ${ }^{7)}$ は, 強還元下での焼成における収縮は $\mathrm{Cr}_{2} \mathrm{O}_{3}$ 粒子表面に $\mathrm{Cr}_{3} \mathrm{O}_{4}$ の上うな可塑的な相の薄膜の 形成によって起こることを，また Toker ら ${ }^{8}{ }^{8}$ は低い酸素 分圧下で “off-stoichiometry” の生ずることを指摘して いる). 本実験ではそれと同時に, $\mathrm{CO}$ ガスと $\mathrm{N}_{2}$ ガス とが存在していることから考えて，その無秩序になった 表面への $\mathrm{CO}$ や $\mathrm{N}_{2}$ の吸着や一時的な溶解も考えられる (このような状態になった $\mathrm{Cr}_{2} \mathrm{O}_{3}$ 粒子表面付近の $\mathrm{Cr}-\mathrm{O}-$ $\mathrm{C}-\mathrm{N}$ 系のものとみられる相を, 前報1) と同じ意味で一 応不安定相と呼ぶ)。そしてこの不安定相が“液相のあ る焼結”の場合の液相と同様な作用を寸ることによっ て, $\mathrm{Cr}_{2} \mathrm{O}_{3}$ のち密化焼結がもたらされたものと考えられ る.

しかるに $\mathrm{Cr}_{2} \mathrm{O}_{3}-\mathrm{Cr}$ 混合成形体の場合には, 前述した ように $\mathrm{Cr}$ の大部分が $\mathrm{Cr}_{2}(\mathrm{C}, \mathrm{N})$ になるにしても, 図 3 に示したように $\mathrm{Cr}$ 粉末成形体が炭素粉末中で加熱さ れた場合にも少量の $\mathrm{Cr}_{2} \mathrm{O}_{3}$ が生成していることから推察 して, $\mathrm{Cr}_{2} \mathrm{O}_{3}$ 粒子の場合と同様に, $\mathrm{Cr}_{2}(\mathrm{C}, \mathrm{N})$ 粒子表面 付近でも上記の不安定相の生成が起こり得るとみられ る. そしてその不安定相が, $\mathrm{Cr}_{2} \mathrm{O}_{3}$ の場合と同じように ち密化を促進させる作用をしたものと推察される。その ため, $\mathrm{Cr}$ の混合割合の多い場合でさえも $\mathrm{Cr}_{2} \mathrm{O}_{3}$ の場合 と同様にち密に焼結されたものと考えられる.

\section{6. 総 括}

$\mathrm{Cr}_{2} \mathrm{O}_{3}$ と $\mathrm{Cr}$ の混合粉末成形体の炭素粉末中での焼結 について，及びこの焼結中に生成する $\mathrm{Cr}_{2}(\mathrm{C}, \mathrm{N})$ につ いて調べた結果, 次のことが明らかとなった.

(1) Cr 粉末成形体は, 炭素粉末中で焼成されると, 空気に由来する $\mathrm{N}_{2}$ や $\mathrm{CO}$ ガスと $500^{\circ} \sim 600^{\circ} \mathrm{C}$ から反 応し, $\mathrm{Cr}_{2}(\mathrm{C}, \mathrm{N})$ と少量の $\mathrm{Cr}_{2} \mathrm{O}_{3}$ を生成し, $700^{\circ} \sim$ $1100^{\circ} \mathrm{C}$ ではそのほかに $\mathrm{CrN}$ を生成する.

(2) 生成する $\mathrm{Cr}_{2}(\mathrm{C}, \mathrm{N})$ 結晶中に含まれる $\mathrm{C}$ の割 合は， $1100^{\circ} \mathrm{C}$ 以下の焼成では 10 atom\% であり，それ 以上の温度では直線的に減少し, $1500^{\circ} \mathrm{C}$ の焼成では 4 atom\% となる.

(3) $1500^{\circ} \mathrm{C}$ の焼結で $95 \%$ 以上の相対密度の $\mathrm{Cr}_{2} \mathrm{O}_{3}$ と $\mathrm{Cr}_{2}(\mathrm{C}, \mathrm{N})$ とからなる複合焼結体が得られ,約 $60 \% \mathrm{Cr}$ 成形体からは $99 \%$ 以上の相対密度のち密焼結体が得ら れる。

謝辞 セントラル硝子 (株) 松阪研究所の田㴊平次氏には 焼結体の EPMAによる元素分析や生成化合物の固定に関し種々 御協力を頂き, 深く感謝致します。 


\section{文献}

1）山口明良, 鶟協, 88, 24-30 (1980).

2) K. Schwerdtfeger, Trans. Met. Soc., AIME, 289 [9] 1432-38 (1967).

3) ASTM 27-127.

4) P. Ettmayer, Monatsh. Chem., 97, 1248-57 (1966).

5) S.K. Storms, "The Refractory Carbide", Acad. Press
N.Y. (1967).

6) H. Lux and L. Elerle, Chem. Ber., 94, 1567-71 (1961).

7) H.E.N. Stone, Metallugia, [4] 152-54 (1968).

8) N. Toker and L. S. Darken, Geochimica et Cosmochica Acta, 39, 874-52 (1975).

論文・Paper

\title{
$\mathrm{Na}_{2} \mathrm{O}-\mathrm{Al}_{2} \mathrm{O}_{3}-\mathrm{B}_{2} \mathrm{O}_{3}, \mathrm{CaO}-\mathrm{Al}_{2} \mathrm{O}_{3}-\mathrm{B}_{2} \mathrm{O}_{3}$ 及びNa $\mathrm{Na}_{2} \mathrm{O}-\mathrm{MgO}-\mathrm{B}_{2} \mathrm{O}_{3}$ 系ガラス中の $\mathrm{Cu}^{2+}$ イオンの光吸収及び ESR スペクトル
}

\author{
作 花 済 夫・西雪 敏 紀 \\ (三重大学 工学部 工業化学科)
}

\begin{abstract}
$\mathrm{Na}_{2} \mathrm{O}-\mathrm{Al}_{2} \mathrm{O}_{3}-\mathrm{B}_{2} \mathrm{O}_{3}, \mathrm{CaO}-\mathrm{Al}_{2} \mathrm{O}_{3}-\mathrm{B}_{2} \mathrm{O}_{3}$ 及び $\mathrm{Na}_{2} \mathrm{O}-\mathrm{MgO}-\mathrm{B}_{2} \mathrm{O}_{3}$ 系ガラス中の $\mathrm{Cu}^{2+}$ イオンの光吸 収スペクトルを測定し, ガラス組成と吸収ピーク波数の関係を調べた。その結果, アルカリ酸化物 の $\mathrm{Na}_{2} \mathrm{O}$ は $\mathrm{Cu}^{2+}$ の吸收ピーク波数に最も著しく影響し，ガラス中の $\mathrm{Na}_{2} \mathrm{O}$ の含有量が $40 \mathrm{~mol} \%$ をこえるとピーク波数は著しく増大すること, アルカリ土類酸化物である $\mathrm{CaO}$ 及び $\mathrm{MgO}$ の吸収 ピーク波数に対する効果はアルカリ酸化物上り小さいことが分った。 また $\mathrm{Na}_{2} \mathrm{O}-\mathrm{Al}_{2} \mathrm{O}_{3}-\mathrm{B}_{2} \mathrm{O}_{3}$ 及び $\mathrm{CaO}-\mathrm{Al}_{2} \mathrm{O}_{3}-\mathrm{B}_{2} \mathrm{O}_{3}$ 系ガラスについて $\mathrm{Cu}^{2+}$ の $\mathrm{ESR}$ スペクトルを測定し，これらのガラスにおける $\mathrm{ESR}$ パラメーターのガラス組成による変化の様子は, 吸収ピーク波数の変化の様子とほぼ対応し ていることを明らかにした。

(1980 年 1 月 7 日受付)
\end{abstract}

\section{Optical Absorption and ESR Spectra of $\mathrm{Cu}^{2+}$ Ions in $\mathrm{Na}_{2} \mathrm{O}-\mathrm{Al}_{2} \mathrm{O}_{3}-\mathrm{B}_{2} \mathrm{O}_{3}$, $\mathrm{CaO}-\mathrm{Al}_{2} \mathrm{O}_{3}-\mathrm{B}_{2} \mathrm{O}_{3}$ and $\mathrm{Na}_{2} \mathrm{O}-\mathrm{MgO}-\mathrm{B}_{2} \mathrm{O}_{3}$ Glasses}

\author{
Sumio SAKKA and Toshiki NISHIYUKI
}

(Department of Industrial Chemistry, Faculty of Engineering, Mie University, Tsu-shi 514)

\begin{abstract}
Absorption spectra of $\mathrm{Cu}^{2+}$ ions were measured in $\mathrm{Na}_{2} \mathrm{O}-\mathrm{Al}_{2} \mathrm{O}_{3}-\mathrm{B}_{2} \mathrm{O}_{3}, \mathrm{CaO}-\mathrm{Al}_{2} \mathrm{O}_{3}-\mathrm{B}_{2} \mathrm{O}_{3}$ and $\mathrm{Na}_{2} \mathrm{O}-\mathrm{MgO}-\mathrm{B}_{2} \mathrm{O}_{3}$ glasses. All the glasses exhibited a broad absorption band peaking at $12300 \sim 15200 \mathrm{~cm}^{-1}$. The following correlations between glass composition and absorption peak wave number were obtained. $\mathrm{Na}_{2} \mathrm{O}$ had the most significant effect on the peak wave number, causing the shift of the peak position towards higher wave numbers with increasing $\mathrm{Na}_{2} \mathrm{O}$ content. The shift was especially large when the $\mathrm{Na}_{2} \mathrm{O}$ content increased beyond $40 \mathrm{~mol} \%$. This was interpreted by the change of coordination of $\mathrm{Cu}^{2+}$ ions and consistency or disruption of glass network. $\mathrm{CaO}$ and $\mathrm{MgO}$ had less effect on the peak wave number. ESR spectra of $\mathrm{Cu}^{2+}$ ions were also measured in $\mathrm{Na}_{2} \mathrm{O}-\mathrm{Al}_{2} \mathrm{O}_{3}-\mathrm{B}_{2} \mathrm{O}_{3}$ and $\mathrm{CaO}-\mathrm{Al}_{2} \mathrm{O}_{3}-\mathrm{B}_{2} \mathrm{O}_{3}$ glasses, which gave parameters $g_{\|}$and $A_{\|}$. The $\mathrm{Na}_{2} \mathrm{O}$ content affected these ESR parameters considerably but $\mathrm{Al}_{2} \mathrm{O}_{3}$ and $\mathrm{CaO}$ had no pronounced effect. This indicated that the variation of ESR parameters with the glass composition resembled that of the peak wave number.

[Received January 7, 1980]
\end{abstract}

Key-words : Absorption spectra, ESR spectra, $\mathrm{Cu}^{2+}$ ions, Borate glasses, Free anions, Glass structure, Jahn-Teller effect 